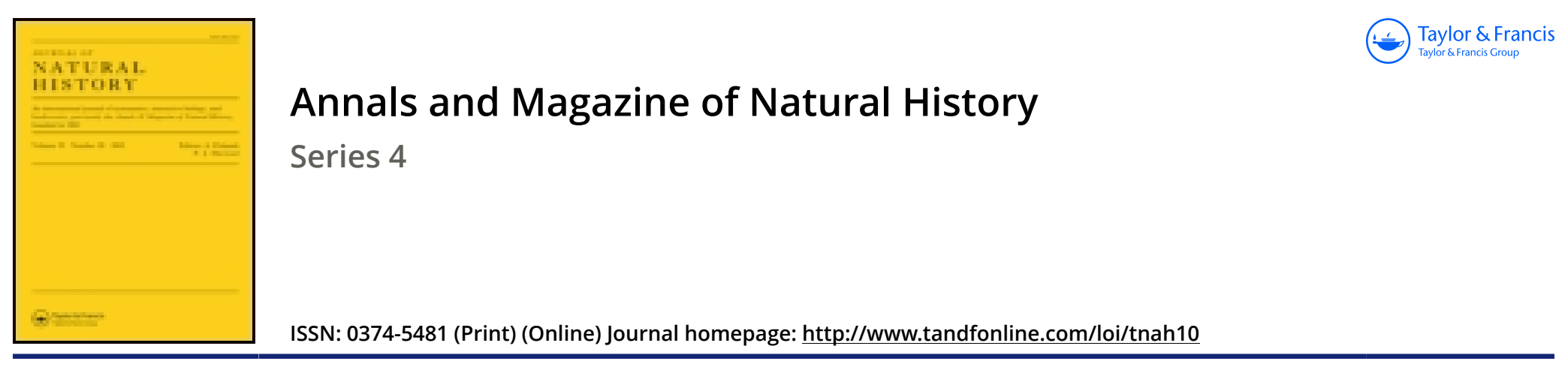

\title{
L.-Notes on the small spotted eagle of Northern Germany, Aquila maculata (Gm.)
}

\section{H.E. Dresser F.Z.S.}

To cite this article: H.E. Dresser F.Z.S. (1874) L.-NNotes on the small spotted eagle of Northern Germany, Aquila maculata (Gm.), Annals and Magazine of Natural History, 13:77, 373-375, DOI: $10.1080 / 00222937408680880$

To link to this article: http://dx.doi.org/10.1080/00222937408680880

册 Published online: 13 Oct 2009.

Submit your article to this journal $[\pi$

Џ Article views: 1

Q View related articles $₫$ 
second, third, and fourth segments have at their basal margins a bright yellow fascia, the second being narrowest; the apical segments yellow; the fascia on the second segment expands laterally into an irregular ovate spot; beneath rufo-testaceous.

$H a b$. South Brazil.

This species is in the possession of Dr. Hermann Müller, of Lippstadt.

\section{Centris lanosa.}

Centris lanosa, Cresson, Hym. Texana, p. 284, ${ }^{\star}$.

Hab. Texas.

[To be continued.]

\section{L.-Notes on the Small Spotted Eagle of Northern Germany, Aquila maculata $(G m$.$) . By H. E. Dresser, F.Z.S.$}

For some time I have been carefully working at the most difficult group amongst the eagles, that comprising those usually known by the name of "Spotted" Eagles, and have by no means yet been able to elucidate matters to my satisfaction. A day or two ago, however, my friend and late colleague, $\mathrm{Mr}$. R. B. Sharpe, showed me the proof-sheets of a portion of his Museum catalogue, now in the process of publication; and I observed that he therein uses the name of Aquila noevia for the small Pomeranian and North-German Spotted Eagle. Although this species, in common with the larger Spotted Eagle which is found in Europe and Asia, has so long borne this name, I convinced myself, some months ago, that it certainly does not belong to it, though I am by no means sure to which species Gmelin's name of nevia should apply. I have, however, never published any information I have acquired on this subject; but as Mr. Sharpe, to whom I communicated some portion of it, wishes to refer to my notes in his catalogue, I have arranged with him to publish a short notice, giving the reasons why I refuse to accept the title of Aquila navia for the smaller Spotted Eagle. They are as follows:-J. F. Gmelin, who first referred to an eagle under the name of Falco noevius (Syst. Nat. i. p. 258. no. 49), which has generally been looked on as being the Small Spotted Eagle, bases his description on that of Brisson's Aigle tacheté (Orn. i. p. 425. no. 4, 1760). Brisson, however, does not describe the bird from a specimen in his own possession, but refers to other authors, some of whose works (as, for instance, the one first mentioned, that of Schwenckfeld) are not to be had for reference. He refers, 
however, to a plate in Frisch's 'Vögel Deutschlands' as giving an accurate representation of his "Aigle tachete," in the following words :- "Buteo. Frisch. hujus icon accurata tab. 71." I possess a copy of Frisch's work; and on reference to the plate I found that the bird there represented is any thing but the Spotted Eagle, and might, I think, except for the partially feathered tarsi, possibly be meant to represent the Golden Eagle, though it does not agree with any stage of plumage of that bird which I have seen. It represents a large blackish brown eagle, regularly though indistinctly marked (so far as can be ascertained), by the centres of the feathers being darker than the outer portions; and the feathering on the tarsus only extends down to within about one third of the base of the claws, this latter portion being bare. Frisch, in his letterpress, speaks of it as the Stein-Adler or GänseAcor (the former being the German appellation for the Golden Eagle), and says that it is somewhat smaller than the SeaEagle. He further states that it has the tarsi only partly feathered, and is blackish brown in colour, like his Aquila melanaëtus, which is evidently the young of the Sea-Eagle. He speaks of having kept one for some time in captivity; and, so far as I can judge, the bird he had was a young Golden Eagle, more especially as he says that it inhabits rocky places and high mountains. He further writes that he thinks it may be a buzzard (" ich halte nicht ohne Grund dafür, es sey dieses der rechte Busaar oder Bushard"). The above, I think, clearly shows that the bird figured by Frisch, to which Brisson refers as being an accurate representation of his "Aigle tachete," cannot possibly be the Spotted Eagle.

To return to Brisson, I may point out several reasons why his description cannot possibly refer to the small Spotted Eagle. He gives its total length as being 2 feet 7 inches and 6 lines, or, in our English measure, 33.7 inches, which utterly precludes its being this species, as an old and large female only measures in the skin 25 inches in length. He further speaks of the throat being dirty white, the underparts of the wings spotted, the underparts of the body generally dull ferruginous, the legs covered with dull ferruginous feathers and spotted with white, and the tail-feathers white at the base and the end, and otherwise dark ferruginous marked with large transverse brown spots, none of which characters agrees with young spotted specimens of this bird which I possess. I must confess that I am utterly unable to discover what species it is to which Brisson refers, but am quite convinced that it is not the small Spotted Eagle, which I hold must bear the name of Aquila maculata (Gm.), ex Lath. 
J. F. Gmelin (Syst. Nat. i. p. 258. no 50) describes this eagle as follows :- "Longitudo bipedalis. Rostrum magnum et ungues nigri ; irides cinereæ ; pennæ scapularum et tectrices alarum apice macula ovali albicante insignitæ; dorsi maculis coloris bubalini; venter similibus lineis striatus," which description agrees well with a specimen in my collection from Silesia. He further refers to Latham, of whose description (Synopsis, i. p. 38. no. 15, 1781) he has evidently made use in giving the above characters. Latham's description is most clear, and certainly refers to the small North-German Spotted Eagle; and the only measurement he gives (the total length), which he says is 2 feet, agrees precisely with specimens of this bird in my possession. He states that his description was taken from a specimen in good condition in the British Museum, but he does not say where it was obtained.

I may add that on showing Mr. Sharpe my reasons for using the name of maculata instead of noevia for the present species, he quite agrees with me in the propriety of so doing.

LI.-Description of an apparently new Species of Hummingbird of the Genus Eriocnemis. By D. G. Elciot, F.L.S., F.Z.S., \&c.

\section{Eriocnemis chrysorama.}

Top of head, back, flanks, breast, and abdomen brilliant metallic fiery red, darkest on the head; chin and throat metallic golden yellow; upper tail-coverts, extending half the length of tail, metallic yellowish green; under tail-coverts, basal half white, remainder metallic blue; wings purplish brown; tail much forked, steel-black ; tufts on tarsi large, pure white; bill black; small spot on base of mandible, next to the chin, yellow, perhaps red in life. Total length $4 \frac{1}{4}$ inches, wing $2 \frac{1}{4}$, tail $1 \frac{3}{4}$, bill $\frac{7}{8}$.

This very brilliant and handsome bird approaches closest to the E. mosquera, and resembles it somewhat in the colour of the lower parts, but is more brilliant and fiery. It is, however, smaller in all its measurements except the bill. The throat-mark is very broad, and extends quite down to the breast.

I do not know the habitat of this species; but the specimen was stated to have come from Ecuador. 